\title{
Analysis the Functional Characteristics of Self Help Groups in Pali District of Rajasthan, India
}

\author{
Hemlata Saini $^{1 *}$ and M. L. Meena ${ }^{2}$ \\ ${ }^{1}$ Department of Agricultural Extension and communication, BACA, AAU, \\ Anand-388110, India \\ ${ }^{2}$ ICAR-CAZRI, Krishi Vigyan Kendra, Pali-Marwar (Rajasthan) 306 401, India \\ *Corresponding author
}

\section{A B S T R A C T}

\section{Keywords}

SHG,

characteristics, group formation and analysis

\section{Article Info}

Accepted:

12 February 2020

Available Online:

10 March 2020
The study examines the functional characteristics of rural women in selfhelp groups in Pali district of Rajasthan by interviewing 150 rural women from 30 self-help groups. It is revealed that majority of the groups scored low on group processes, high group sustainability, and high confirmation to group norms. Maximum number of groups was found to be discussing only issues related to thrift, economic activities and personal problems and most of the self-help groups were formed for achieving life security by saving for future. The study suggests qualitative improvement required for the functioning of the SHGs.

\section{Introduction}

The SHGs are viable alternative in achieving the objectives of women empowerment. Individually, poor women tend to be erratic and uncertain in her behavior. Group membership smoothes such rough edges making her more reliable. Participation of women in SHGs makes a significant impact on their empowerment, both in social and economic terms. It helps to bring about awareness among rural women about savings, education, health, environment, cleanliness family welfare etc and makes themes self- reliant. Women constitute half of the world's population, contribute about two-thirds of its working hours, receive one-tenth of the world's income and own less than onehundred of the world's property.

They share abundant responsibility and perform a wide spectrum of duties. The existence of women in a state of economic, political, social and knowledge disempowerment is known to be a major hindrance to economic development. The self-help group is an alternative approach to achieve the objectives of the rural 
development. SHG is a viable organized setup to disburse micro-credit to the rural women and encouraging them to enter into entrepreneurial activities. Formation of Self Help Groups (SHGs) has greatly helped rural women to understand their rights, access to information, economic independence, freedom of expression, confidence building, access to credit, improve their personality and respect in the society etc. self-help group is an approach through which efforts are being made by the government and non-government organizations with an intention to pool both human and material resources to empower women in rural areas.

The empowerment of rural women through SHGs would lead to benefit not only the individual women and women groups but also the family and community as a whole through collective action and solidarity. Cohesion enables the members of the group to perceive common interests and act collectively. In recent years, SHGs are emerging as an important alternative mechanism to meet the urgent credit needs of poor through thrift. Group cohesiveness, group sustainability, cooperation among group members and confirmation to group norms are the factors mostly affecting the functioning of the groups in getting good profits. The present study analyzed the functional characteristics of SHGs in terms of group processes, group sustainability, conformity to group norms, critical issues of group meetings and motivation for forming into SHGs.

\section{Materials and Methods}

The study was conducted in Pali district of Rajasthan. Five villages Hemawas, Sonaimanjhi, Roopawas, Gadwara and Kharda were selected purposely as they were having highest number of SHGs. Totally 30 SHGs were selected by using proportionate random sampling method from selected villages. From each selected SHG, five women were drawn randomly to represent the group. Thus finally, there were 150 rural women respondents for the study. Five functional characteristics viz., group process, group sustainability, conformity to norms, critical issues of group meetings and motivation for forming into SHG groups were analyzed. Data was collected by personal interview method by using pre-tested schedule developed for the study.

\section{Results and Discussion}

\section{Group processes}

Response analysis of group processes viz., group cohesiveness, group role differentiation, group leadership and group communication is presented in Table 1

\section{Group cohesiveness}

Majority (90.09 \%) of the groups indicated that members were satisfied with the group functioning and comfortable to work with other members. Further, 83.34 per cent groups expressed that members rely on one another in the group and there is a healthy competition among group members. Majority of 80.00 per cent group members encourage each other, 76.67 per cent groups worked well and 70.00 per cent groups felt that their group manages conflicts/disagreements effectively. Hence this situation needs to be maintained by every group leader by motivating their group leader by motivating their group members to work untidy for higher benefits through SHGs. The findings confirm with the findings of Singh, et al., (2010).

\section{Group role differentiation}

Most $(93.33 \%)$ of the groups expressed that members are equally consulted for the development of the group and group members 
have inclination to take up allotted work and 70.00 per cent groups indicated that the work of the group is well divided among all the members and have equal say in the decision making process of the group.

Further, 63.33 per cent groups said true for all the members actively participate in the activities of the group and somewhat true for group leader solely responsible for majority of tasks. It is very clear from the above figures that they are following democratic approach and equal importance is being given to all members. It is a good sign for better functioning of the group as a whole. The findings confirm with the findings of Mehra, et al., (2010) and Muthuramu et al., (2015).

\section{Group leadership}

A great majority of groups indicated that, group organizer works much for group success $(90.00 \%)$, group organizer have good relations with other leaders and groups (83.34\%) and group organizer is approachable and dependable (80\%). Further, 70.00 per cent group gave response of somewhat true for the statement group organizer has no control on the group members and 66.70 per cent groups felt that the group organizer is sympathetic and helpful in solving others' problems at work or in their personal life. Hence further to strengthen the leadership abilities they need to be selected by using right methods and trained to work as an effective leader. The findings confirm with the findings of Muthuramu et al., (2015), Bhatnagar and Rathore (2015) and Saidanna and Sailaja (2010).

\section{Group communication}

Almost 90.00 per cent groups expressed that the group members are kept informed about important events, 80.00 per cent groups indicated that the members dependency on informal leader for information was somewhat true. Nearly eighty per cent groups felt that members discuss about their personal problems with others in group, 70 per cent groups informed that friendly and informal interactions occur in the group and 50 per cent groups said that the information flows easily from one clique to another clique in the group. It was mainly due to the homogeneity in terms of castes, location and their interests. The findings confirm with the findings of Kumar, et al., (2008).

\section{Group sustainability of SHGs}

Majority (70.00 \%) groups were having active life groups and high internal lending, 63.33 were having low recoupment of revolving fund and 56.67 per cent were having high extent of defaulters and low status of group savings. The overall picture of group sustainability and it was mainly because group members realized that group profits are their own profits. The findings confirm with the findings of Mishra, (2005).

\section{Confirmation to group norms by SHGs}

From Table 3 it is evident that, majority of the groups always confirmed to meet as scheduled at fixed places and group work (90.00\%), maintaining books and records $(91.60 \%)$ and repaying loan promptly $(66.67 \%)$.

Further, 66.67 per cent of groups rarely confirmed to levy penalty on member's realization about the confirmation to group norms for smooth functioning of the group, 63.33 per cent groups prioritized the needs of members for utilization of thrift and 56.67 per cent groups compulsorily attend meetings. Half of the groups sometimes confirmed to promptly remitting the thrift. The findings confirm with the findings of Tyagi (2015), Meenma et al., (2012) and Gupta and Rahman (2007). 
Table.1 Response analysis of statements of group processes of self-help groups (Numbers of groups $=30)$

\begin{tabular}{|c|c|c|c|c|}
\hline S. No. & Components of group process & $\begin{array}{l}\text { True } \\
\text { F }(\%)\end{array}$ & $\begin{array}{l}\text { Somewhat } \\
\text { true } F(\%)\end{array}$ & $\begin{array}{l}\text { Not true } F \\
(\%)\end{array}$ \\
\hline A. & \multicolumn{4}{|l|}{ Group cohesiveness } \\
\hline 1. & I feel this group worked well tighter & $\begin{array}{c}23 \\
(76.67)\end{array}$ & $7(23.33)$ & 00 \\
\hline 2. & $\begin{array}{l}\text { The group manages conflicts/disagreements } \\
\text { effectively }\end{array}$ & $\begin{array}{c}21 \\
(70.00)\end{array}$ & $7(23.33)$ & $\begin{array}{c}2 \\
(6.67)\end{array}$ \\
\hline 3. & $\begin{array}{l}\text { There is unhealthy competition and criticism } \\
\text { among group members }\end{array}$ & $\begin{array}{c}1 \\
(3.33)\end{array}$ & $4(13.33)$ & $25(83.34)$ \\
\hline 4. & $\begin{array}{l}\text { Member do not encourage/support each other } \\
\text { in the group }\end{array}$ & 00 & $6(20.00)$ & $24(80.00)$ \\
\hline 5. & $\begin{array}{l}\text { I feel dissatisfied and would like to quit the } \\
\text { group }\end{array}$ & 00 & $3(10.00)$ & $27(90.00)$ \\
\hline 6. & $\begin{array}{l}\text { I do not feel comfortable to work with same } \\
\text { group members for other activities }\end{array}$ & 00 & $3(10.00)$ & $27(90.00)$ \\
\hline 7. & Members do not rely one another in the group & 00 & $5(16.66)$ & $25(83.34)$ \\
\hline \multicolumn{5}{|c|}{ B. Group role differentiation } \\
\hline 1. & $\begin{array}{l}\text { The work of the group is well divided among } \\
\text { all the members }\end{array}$ & $\begin{array}{c}21 \\
(70.00)\end{array}$ & $9 \quad(30.00)$ & 00 \\
\hline 2. & $\begin{array}{l}\text { All the members have equal say in the decision } \\
\text { making process of the group }\end{array}$ & $\begin{array}{c}21 \\
(70.00)\end{array}$ & $9(30.00)$ & 00 \\
\hline 3. & $\begin{array}{l}\text { All the members actively participate in the } \\
\text { activities of the group }\end{array}$ & $\begin{array}{c}19 \\
(63.33)\end{array}$ & $11(36.67)$ & 00 \\
\hline 4. & $\begin{array}{l}\text { Members are not equally consulted for the } \\
\text { development of the group }\end{array}$ & $\begin{array}{c}2 \\
(6.67)\end{array}$ & 00 & $28(93.33)$ \\
\hline 5. & $\begin{array}{l}\text { Group leader solely responsible for majority of } \\
\text { tasks }\end{array}$ & $\begin{array}{c}2 \\
(6.67)\end{array}$ & $19(63.33)$ & $9(30.00)$ \\
\hline 6. & $\begin{array}{l}\text { Group members lack inclination to take up } \\
\text { allotted work/responsibility }\end{array}$ & - & $2(6.67)$ & $28(93.33)$ \\
\hline \multicolumn{5}{|c|}{ C. Group leadership } \\
\hline 1. & $\begin{array}{l}\text { Group organizer is sympathetic and helpful in } \\
\text { solving other's problem at work or in their } \\
\text { personal life }\end{array}$ & $\begin{array}{c}20 \\
(66.67)\end{array}$ & $10(33.33)$ & 00 \\
\hline 2. & Group organizer is efficient at group work & $\begin{array}{c}13 \\
(43.33)\end{array}$ & $17(56.67)$ & 00 \\
\hline 3. & $\begin{array}{l}\text { Group organizers has control on group and } \\
\text { individual members }\end{array}$ & $\begin{array}{c}9 \\
(30.00)\end{array}$ & $21(70.00)$ & 00 \\
\hline 4. & $\begin{array}{l}\text { Group organizer do not have good } \\
\text { relationships with other leaders and groups in } \\
\text { the community }\end{array}$ & $\begin{array}{c}2 \\
(6.67)\end{array}$ & $3(10.00)$ & $25(83.34)$ \\
\hline
\end{tabular}




\begin{tabular}{|l|l|c|c|c|}
\hline $\mathbf{5 .}$ & $\begin{array}{l}\text { Group organizer do not work much for group's } \\
\text { success }\end{array}$ & - & $3(10.00)$ & $\mathbf{2 7}(\mathbf{9 0 . 0 0})$ \\
\hline $\mathbf{6 .}$ & $\begin{array}{l}\text { Group organizer is less approachable and } \\
\text { undependable }\end{array}$ & - & $6(20.00)$ & $\mathbf{2 4}(\mathbf{8 0 . 0 0})$ \\
\hline D. & Group communication & & \\
\hline $\mathbf{1 .}$ & $\begin{array}{l}\text { Members discuss about their personal } \\
\text { problems with other members in the group }\end{array}$ & $\begin{array}{c}23 \\
(76.67)\end{array}$ & $7(23.33)$ & $\mathbf{0 0}$ \\
\hline $\mathbf{2 .}$ & $\begin{array}{l}\text { Informal and friendly interactions occurs in the } \\
\text { group }\end{array}$ & $\begin{array}{c}21 \\
(70.00)\end{array}$ & $8(26.67)$ & $\mathbf{1}(\mathbf{3 . 3 3})$ \\
\hline $\mathbf{3 .}$ & $\begin{array}{l}\text { The information flows easily from one clique } \\
\text { to another clique in the group }\end{array}$ & $\begin{array}{c}15 \\
(50.00)\end{array}$ & $12(40.00)$ & $\mathbf{3}(\mathbf{1 0 . 0 0})$ \\
\hline $\mathbf{4 .}$ & $\begin{array}{l}\text { Group members depend on information leader } \\
\text { for getting information }\end{array}$ & $\begin{array}{c}6 \\
(20.00)\end{array}$ & $24(80.00)$ & $\mathbf{0 0}$ \\
\hline $\mathbf{5 .}$ & $\begin{array}{l}\text { The group members are not kept informed } \\
\text { about important events or activities }\end{array}$ & $\mathbf{1}$ & $\mathbf{2}(\mathbf{6 . 6 7})$ & $\mathbf{2 7}(\mathbf{9 0 . 0 0})$ \\
\hline
\end{tabular}

Table. 2 Group sustainability SHGs (Numbers of groups=30)

\begin{tabular}{|l|l|c|c|}
\hline S. No. & Components of group processes & Frequency & $\begin{array}{c}\text { Percentag } \\
\text { e }\end{array}$ \\
\hline $\mathbf{1 .}$ & Active life of the group & 9 & $\mathbf{3 0 . 0 0}$ \\
\hline & Low active life groups & 21 & $\mathbf{7 0 . 0 0}$ \\
\hline & High active life groups & 9 & $\mathbf{3 0 . 0 0}$ \\
\hline $\mathbf{2 .}$ & Level of internal lending & 21 & $\mathbf{7 0 . 0 0}$ \\
\hline & Low internal lending groups & & \\
\hline H. & Exh internal lending groups & 17 & $\mathbf{5 6 . 6 7}$ \\
\hline & Low defaulter groups & 13 & $\mathbf{4 3 . 3 3}$ \\
\hline & High defaulter groups & & \\
\hline 4. & Status of group savings & 17 & $\mathbf{5 6 . 6 7}$ \\
\hline & Low group savings & 13 & $\mathbf{4 3 . 3 3}$ \\
\hline & High group savings & 19 & $\mathbf{6 3 . 3 3}$ \\
\hline & Recoupment of revolving fund & $\mathbf{1 1}$ & $\mathbf{3 6 . 6 7}$ \\
\hline & Low recoupment of revolving fund & & \\
\hline High recoupment of revolving fund & & & \\
\hline
\end{tabular}


Table.3 Response analysis of statements of confirmation of group norms of SHGs (Numbers of groups $=30$ )

\begin{tabular}{|l|l|c|c|c|}
\hline S. No. & Components of group processes & $\begin{array}{c}\text { Always } \\
\text { F (\%) }\end{array}$ & $\begin{array}{c}\text { Sometimes } \\
\text { F (\%) }\end{array}$ & $\begin{array}{c}\text { Rarely } \\
\text { F(\%) }\end{array}$ \\
\hline 1. & $\begin{array}{l}\text { The group meets as scheduled at fixed } \\
\text { place of meetings and group work }\end{array}$ & $28(93.33)$ & $2(6.67)$ & $\mathbf{0 0}$ \\
\hline $\mathbf{2 .}$ & $\begin{array}{l}\text { The group maintains required books and } \\
\text { records }\end{array}$ & $27(90.00)$ & $2(6.67)$ & $\mathbf{1}(\mathbf{3 . 3 3})$ \\
\hline $\mathbf{3 .}$ & Group members repay loan promptly & $20(66.67)$ & $10(33.33)$ & $\mathbf{0 0}$ \\
\hline $\mathbf{4 .}$ & $\begin{array}{l}\text { The needs of members are prioritized for } \\
\text { utilization of thrift }\end{array}$ & $19(63.33)$ & $10(33.33)$ & $\mathbf{1}(\mathbf{3 . 3 3})$ \\
\hline $\mathbf{5 .}$ & $\begin{array}{l}\text { All the members compulsorily attend the } \\
\text { meetings }\end{array}$ & $17(56.67)$ & $12(40.00)$ & $\mathbf{1}(\mathbf{3 . 3 3})$ \\
\hline $\mathbf{6 .}$ & Group members promptly remit the thrift & $15(50.00)$ & $15(50.00)$ & $\mathbf{0 0}$ \\
\hline 7. & $\begin{array}{l}\text { Penalty is levied on members for late } \\
\text { repayment defaulting }\end{array}$ & $\mathbf{5 ( 1 6 . 6 6 )}$ & $\mathbf{5 ( 1 6 . 6 6 )}$ & $\mathbf{2 0}$ \\
\hline
\end{tabular}

Table.4 Distribution of SHGs according to the critical issues discussed in group meetings (Numbers of groups=30)

\begin{tabular}{|l|l|c|c|}
\hline S. No & Critical issues of group meetings & F & $\mathbf{\%}$ \\
\hline $\mathbf{1 .}$ & Only thrift and other financial aspects & 00 & $\mathbf{0 0}$ \\
\hline $\mathbf{2 .}$ & Thrift activities+ economic activities & 2 & $\mathbf{6 . 6 7}$ \\
\hline $\mathbf{3 .}$ & Thrift activities+ economic activities+ personal problems & 11 & $\mathbf{3 6 . 6 7}$ \\
\hline $\mathbf{4 .}$ & $\begin{array}{l}\text { Thrift activities+ economic activities+ personal problems+ } \\
\text { community problems }\end{array}$ & 8 & $\mathbf{2 6 . 6 7}$ \\
\hline $\mathbf{5 .}$ & $\begin{array}{l}\text { All the above+ general welfare and solutions for problems } \\
\text { of women }\end{array}$ & $\mathbf{1 0}$ & $\mathbf{3 3 . 3 3}$ \\
\hline
\end{tabular}

Critical issues discussed in group meetings of SHGs

It could be noticed from Table 4 that 36.67 per cent of the groups discussed thrift activities, economic activities and personal problems. One third $(33.33 \%)$ of groups discussed thrift activities, economic activities, personal problems, community problems and general welfare and solutions of women.
Whereas, 26.67 per cent of groups discussed thrift activities, economic activities, personal problems and community problems and only a negligible per cent $(6.67 \%)$ discussed only thrift activities and economic activities.

It shows their concern about different related aspects for their welfare. The findings confirm with the findings of Khullar and Singh (2007). 
Table.5 Distribution of SHGs according to the motive to form SHGs (Numbers of groups $=30$ )

\begin{tabular}{|l|l|c|c|}
\hline S. No. & Reasons & Frequency & Percentage \\
\hline $\mathbf{1 .}$ & For future savings & 28 & $\mathbf{9 3 . 3 3}$ \\
\hline $\mathbf{2 .}$ & For getting loans at cheaper interests & 21 & $\mathbf{7 0 . 0 0}$ \\
\hline $\mathbf{3 .}$ & To become economically independent & 17 & $\mathbf{5 6 . 6 7}$ \\
\hline $\mathbf{4 .}$ & To overcome financial problems & 15 & $\mathbf{5 0 . 0 0}$ \\
\hline $\mathbf{5 .}$ & To solve the problems collectively & 9 & $\mathbf{3 0 . 0 0}$ \\
\hline $\mathbf{6 .}$ & For improving skills & 8 & $\mathbf{2 6 . 6 7}$ \\
\hline 7. & To avoid the conflicts among neighbours & $\mathbf{3}$ & $\mathbf{1 0 . 0 0}$ \\
\hline
\end{tabular}

\section{Perceived motives for forming SHGs}

Most (93.33\%) of the groups were formed with a motive of future savings, 70 per cent for getting loans at cheaper interests, 56.67 per cent to become economically independent, 50.00 per cent with a motive to overcome financial problems, 30 per cent groups solve the problems collectively and 26.67 per cent groups were formed for improving group members' skills.

The least motives for them to form groups were to avoid the conflicts among neighbours $(10.00 \%)$. It is a clear evidence for the transformation in their attitudes and their concern about the future.

It may be concluded that the concerned agencies and development workers responsible for forming and promoting SHGs like women and child welfare department and non-government organizations has to emphasize and encourage the fruitful discussions of thrift, social and economic activities and different means of savings and investment which benefit not only the personality of women but also the overall development of the society. This kind of inculcating such factors among the group members may be through training programmes, discussion with successful group members at other villages and awareness camps.

\section{References}

Bhatnagar, S. and Rathore, S.S. (2015). Social and economic empowerment of rural women through self help group formation in Jaipur district of Rajasthan. Journal of Krishi Vigyan 2(1):94-96.

Gupta J and Rahman S. (2007). Self Help Groups in India: Impact and sustainability. International Journal of Extension Education, 7:57-60.

Khullar, V. and Singh, R. (2007). Farmers SHGs and organized Agri-business system; Key factors for improving agricultural economy. Asian Journal of Extension Education, 26 (1\&2):117119.

Kumar, V.P. and Asokan, P.K. (2008). Mussel farming technology dissemination to the Self Help Groups. Indian Journal of Extension, 44 (1\&2):112-115.

Meena, M.L., Singh, D. and Dudi, A (2012). Role perception about empowerment of farm women in agriculture in western 
Rajasthan. Asian Journal of Home Science 7(2):237-241.

Mehra J, Chaudhary S, Punjabi N K and Dangi K L. (2010). Role of Self Help Groups in empowerment of rural women in Indore block of Madhya Pradesh. Rajasthan Journal of Extension Education, 17\&18:118-120.

Mishra A. (2005). Participatory Impact Assessment: Case analysis of SHGbank linkage programme in India. Asia Workshop on Next Generation Participatory Monitoring and Evaluation 9-11 November 2005, PRIA, New Delhi, India.

Muthuramu, V., Paulpandi, V.K., Sukthuvel, S., Ramakrishana, K. and Krthik, R. (2015). Empowerment of SHG members of Virudhanagar district throu8gh vocational training on mushroom production. Journal of Krishi Vigyan 2(1):23-26.

Singh A, Sharma S K and Henry C. (2010). Impact of women Self Help Groups in changing socio-economic status of rural families in Bikaner district of Rajasthan. Rajasthan Journal of Extension Education, 17\&18:112-114.

Tayagi, S. (2015). Credit utilization pattern of members of women SHGs and their involvement in decision making in Udaipur, Rajasthan, Journal of Community Mobilization and Sustainable Development, 10(1):100103.

\section{How to cite this article:}

Hemlata Saini and Meena. M. L. 2020. Analysis the Functional Characteristics of Self Help Groups in Pali District of Rajasthan, India. Int.J.Curr.Microbiol.App.Sci. 9(03): 1340-1347. doi: https://doi.org/10.20546/ijcmas.2020.903.156 